\title{
MOLECULAR DIFFERENTIATION OF TWO ANTARCTIC FISH SPECIES OF THE GENUS Notothenia (NOTOTHENIOIDEI: NOTOTHENIIDAE) BY PCR-RFLP TECHNIQUE
}

http://dx.doi.org/10.4322/apa.2014.039

\begin{abstract}
Cintia Machado', Marcia Kiyoe Shimada², Stênio Perdigão Fragoso², Edith Fanta',
\end{abstract} Helena G. Kawall1, Edson Rodrigues ${ }^{3}$, Lucélia Donatti $1^{1, *}$

\footnotetext{
'Departamento de Biologia Celular, Setor de Ciências Biológicas, Universidade Federal do Paraná - UFPR, Curitiba, PR, Brazil ${ }^{2}$ Fundação Oswaldo Cruz, Instituto Carlos Chagas - ICC, Paraná, Curitiba, PR, Brazil

${ }^{3}$ Laboratório de Bioquímica, Instituto Básico de Biociências - IBB, Universidade de Taubaté - UNITAU, Taubaté, SP, Brazil *e-mail: donatti@ufpr.br
}

Abstract: The Antarctic fish Notothenia rossii and Notothenia coriiceps were selected as target organisms for studies of biomarker responses of environmental monitoring research of Admiralty Bay, King George Island. In this case, molecular taxonomy analysis of the referred population became an important study subject in order to increase the knowledge of especies diversity. The taxonomy of Antarctic fish has been predominantly based on morphological characteristics rather than on genetic criteria. A typical example is the Notothenia group, which consists of $\mathbf{N}$. coriiceps, $N$. neglecta and $\mathbf{N}$. rossii. The Polymerase Chain Reaction and Restriction Fragment Length Polymorphism (PCR-RFLP) technique was used to determine whether N. neglecta and $N$. coriiceps are different or whether they are the same species with morphological, physiological and behavioural variability. N. rossii was used as control. Mitochondrial DNA (mtDNA) was isolated from muscle specimens of N. neglecta, $N$. coriiceps and $N$. rossii, which were collected in Admiralty Bay, King George Island. The DNA was used to amplify a fragment (690 base pairs) of the coding region of the mitochondrial gene for NADH subunit 2. Further, the amplicon was digested with following restriction enzymes: DdeI, HindIII and RsaI. The results showed a variation of the digestion pattern of the fragment amplified between $N$. rossii and $N$. coriiceps or $N$. neglecta species. No differences were found between $N$. coriiceps and N. neglecta specimens.

Keywords: Notothenia species, DNA mitochondrial, NADH-2, PCR-RFLP

\section{Introduction}

The Antarctic fish Notothenia rossii and Notothenia coriiceps were selected as target organisms for studies of biomarker responses of environmental monitoring research proposed in Module 3 INCT-APA (Instituto Nacional de Ciência e Tecnologia Antártico de Pesquisas Ambientais) for Admiralty Bay, King George Island (Rodrigues et al., 2009). In this case, molecular taxonomy analysis of the referred population became an important study subject to increase the knowledge of the diversity of this species.
The species Notothenia coriiceps was first described by Richardson in 1844. Nybelin (1951) described N. neglecta as a new species of the genera, contested in 1966 by DeWitt who considered $N$. neglecta a subspecies of $N$. coriiceps. Fischer and Hureau (1988) supported the hypotheses that $N$. coriiceps and $N$. neglecta are distinct species, presenting differences in the number of fin rays of the pectoral and second dorsal fins, interorbital width and head length. Nowadays, most authors consider that $N$. coriiceps and 


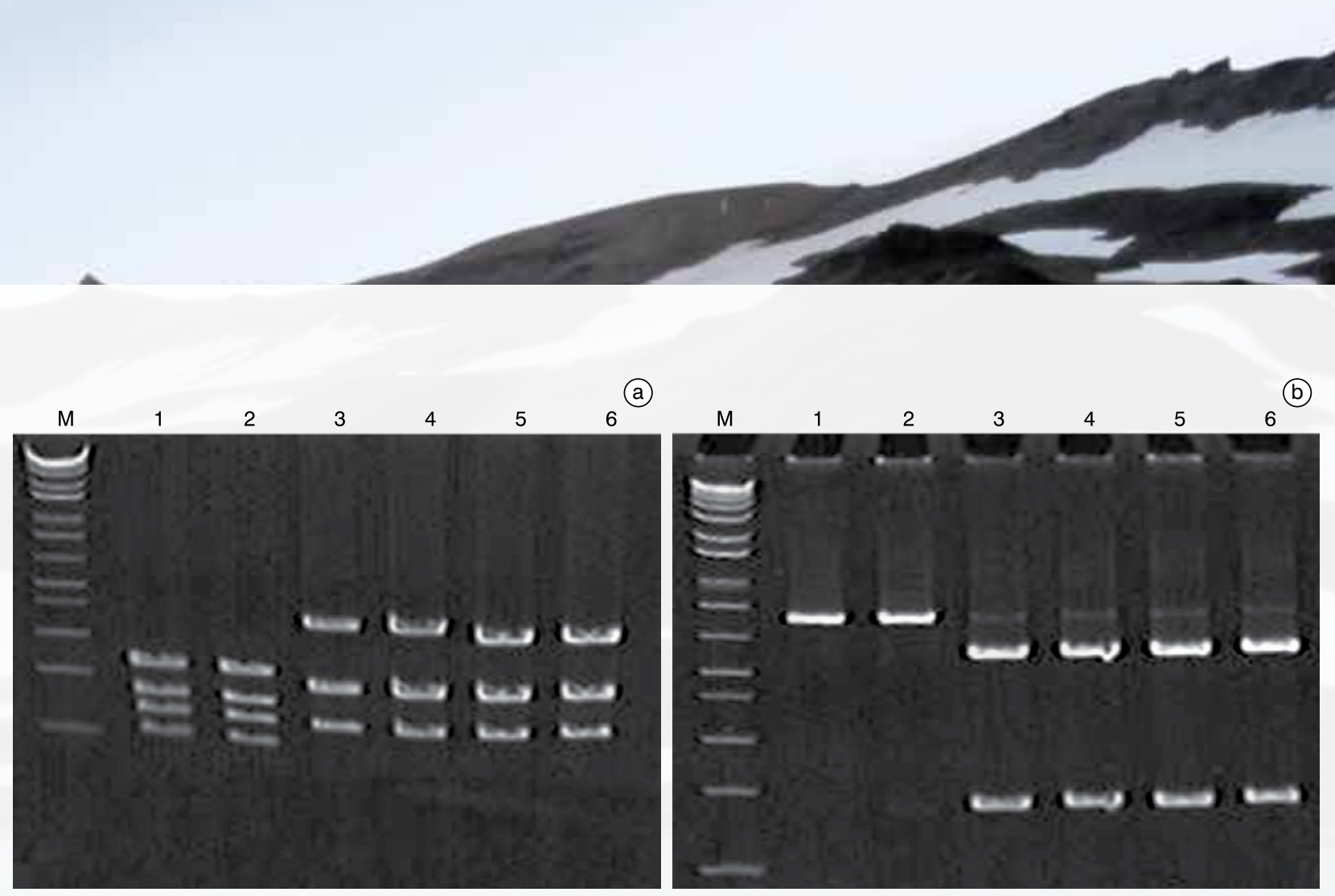

(b)

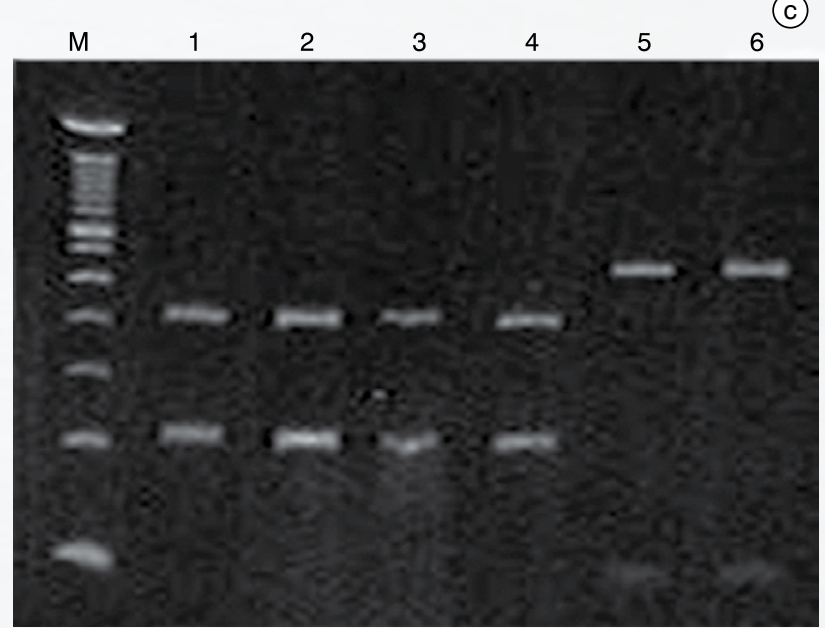

Figure 1. Digestion profile of a fragment (690 base pairs) of the coding region amplified of the mitochondrial gene of the subunit 2 of the NADH using PCR-RFLP technique. a) Amplicon digested by restriction enzyme Ddel. Lines 1 and 2 corresponding to N. rossii specie. Lines 3 and 4: $N$. coriiceps. Lines 5 and 6: N. neglecta; b) Amplicon digested by restriction enzyme Hindlll. Lines 1 and 2 corresponding to N. rossii specie. Lines 3 and 4: N. coriiceps. Lines 5 and 6: N. neglecta; c) Amplicon digested by restriction enzyme Rsal. Lines 1 and 2 corresponding to N. coriiceps specie. Lines 3 and 4: N. neglecta. Lines 5 and 6: N. rossii. M: $1 \mathrm{~kb}$ Plus Ladder (Invitrogen).

specimens, by the digestion profile obtained for the DdeI, HindIII and RsaI restriction enzymes (Figure 1).

\section{Discussion}

The species N. coriiceps, described by Richardson 1844, is largely distributed in shallow waters of the Southern Ocean and found in high densities in Admiralty Bay. It presents a great deal of morphological variation. Nybelin (1951) described N. neglecta as a new species of the genera. Fischer and Hureau (1988) considered N. coriiceps and N. neglecta as a distinct species, showing differences in the number of fin rays of the pectoral and second dorsal fins, interorbital width and head length. In 1966, DeWitt considered N. neglegta as a subspecies of $N$. coriiceps justifying that Nybelin had used a small number of samples to present its classification (Gon \& Heemstra, 1990).

\section{Conclusion}

The results of the study presented here confirmed that $N$. coriicepsis genetically different to N.rossii, being two 


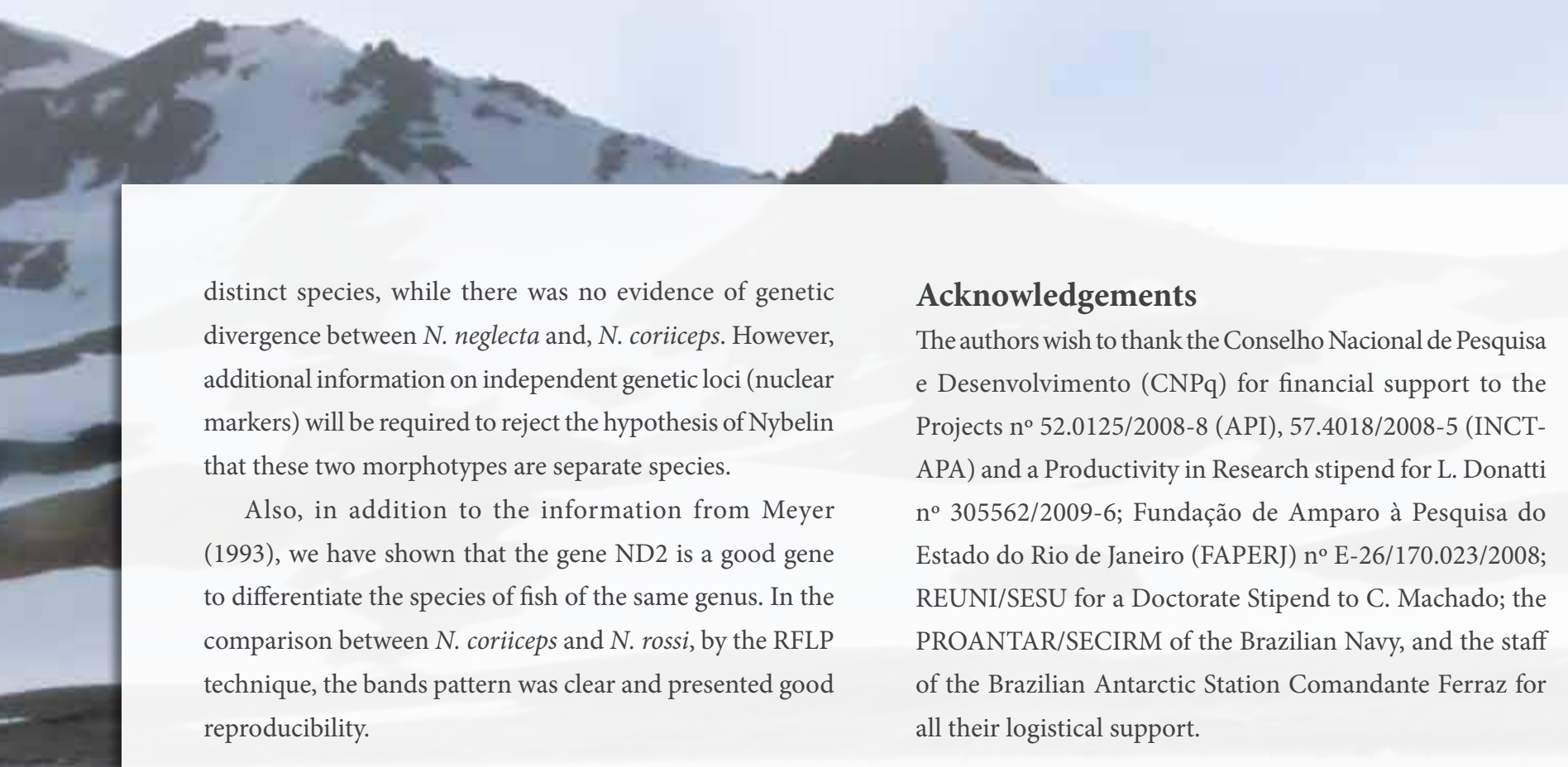

\section{References}

Eastman, J.T. (1993). Antarctic fish biology. San Diego: Academic Press, 322 pp.

Eastman, J.T. \& Eakin, R.R. (2000).An updated species list for notothenioid fish (Perciformes; Notothenioidei), with comments on Antarctic species. Archive of Fishery and Marine Research. 48(1), 11-20.

Fischer, W. \&Hureau, J.C. (1988). Oceano austral. 1985. Vol II. Roma: Organizacion de las Naciones Unidas para Alimentacion e la Agricultura, $471 \mathrm{pp}$.

Gon, O.\& Heemstra, P.C. (1990). Fishes of the Southern Ocean.J. L. B. Smith Institute of Ichthyology. South Africa: Grahamstown, $462 \mathrm{pp}$.

Kock, K.H. (1992). Antarctic fish and fisheries; studies in polar research. Cambridge: Cambridge University Press, 359 pp.

Meyer, A. (1993). Evolution of mitochondrial DNA in fishes. In: Hochachka and Mommsen, Biochemistry and molecular biology of fishes, vol.2. Elsevier Science Publishers, New York, pp. 1-38.

$\mathrm{NCBI}$ - National Center for Biotechnology Information (2004). Available from: <www.ncbi.nlm.nih.gov>. Accessed in August $11^{\text {th }} 2004$.

Rodrigues, E.; Donatti, L.; Vani, G.S.; Lavrado, H.P.; Rios, F.S.; Suda, S.N.K.; Piechnik, C.A.; Machado, D.; Rodrigues Junior, E.; Oliveira, M. F.; Silva, F.B.V. \& Cettina, L.B. 2009. Natural and anthropic impact assessment on biochemical and histopathological biomarkers of fishes and invertebrates at coastal region of Admiralty Bay - King George Island. Annual Activity Report of Institute of Science and technology Antarctic Environmental Research. São Carlos, pp. 44-49. 